\title{
Living with intestinal stoma: the construction of autonomy for care ${ }^{1}$
}

\author{
Débora Poletto 2 \\ Denise Maria Guerreiro Vieira da Silva ${ }^{3}$
}

Objective: to investigate the care undertaken in the health services for people with intestinal stoma, from the perspective of articulating the actions proposed in the Amplified and Shared Clinic, with a view to promoting autonomy. Method: qualitative study. Participants: 10 people who received a stoma, and their family members. Data was collected between 10th January and 30th June 2011, through two semi-structured interviews. Analysis was through the stages: anxiety, synthesis, theorization and recontextualization. Results: presented in the categories: (1) the need to carry out stoma care; (2) receiving health support and care after discharge from hospital; (3) returning to daily activities and social reinsertion. Conclusion: the study identified common factors which influence the process of development of autonomy and the relationship which health professionals have with this achievement.

Descriptors: Health Education; Ostomy; Personal Autonomy.

\footnotetext{
${ }^{1}$ Paper extracted from Master's Thesis "Avaliação qualitativa da atenção à saúde na perspectiva das pessoas com estoma intestinal", presented to Universidade Federal de Santa Catarina, Florianópolis, SC, Brazil.

2 MSc, Professor, Faculdade Fátima Educação, Caxias do Sul, RS, Brazil.

${ }^{3}$ PhD, Professor, Universidade Federal de Santa Catarina, Florianópolis, SC, Brazil.
} 


\section{Introduction}

A person who has surgery for intestinal stoma faces a condition which includes the diversion of waste products to the abdomen and a consequent change in body image. This type of surgery involves physical issues related to the loss of body integrity, violation of hygiene rules, loss of sphincter control with loss of control of feces and involuntary release of gases and odor. There may also be change in self-esteem and selfconcept, feelings of uselessness, depression, sadness, and rejection, among others. These changes may result in profound alterations in lifestyle, social relationships and daily routines ${ }^{(1-3)}$.

To attend these people integrally, health professionals and services need to be prepared and available. A person newly in this condition needs new knowledge in relation to their personal care. In addition to understanding the stoma, the technical skills and the physical and biological care, the person also needs attention directed at their social adaptation, and to emotional and spiritual care. Mastering these skills and knowledge is a basis for accepting, and coping with, the new condition ${ }^{(4)}$.

The person, as a unique individual, is the result of their subjectivity, influences from their context, and interactions with other people. The factors responsible for the construction of this individual uniqueness vary. The biological and subjective differences, inserted into an organizational, political, cultural, social and religious context, are products of this uniqueness ${ }^{(5-6)}$. Because of this, all people need the health services to provide care with a wider view, taking in this variability between the subjects, the better to understand the condition and support the promotion of the co-construction of autonomy.

The term 'autonomy' comes from the Greek; 'auto' means 'own', and 'nomos', 'law, rule'. In this sense, autonomy leads one to the idea of personal freedom to define one's own rules(7-8). Autonomy is a person's capacity to understand themselves and the context in which they are inserted and, through this, to know how to act upon themselves and this context. Autonomy is not an absolute concept, or a static state; it is a dynamic, gradual process, with the possibility of improvement, and has variable degrees in line with coefficients relating to the criteria of the person her- or him-self(5-6).

When speaking of the co-construction of autonomy, it is considered that health professionals can assist people in widening their knowledge, working with the aim of presenting the technical dimension involved in their health process, and of supporting the development of their reflexive ability in relation to the different situations and contexts, intervening in their dependency network and decision-making, recognizing the consequences and rescuing and/or promoting their autonomy ${ }^{(5-6)}$.

It's important to emphasize that the directive of the National Policy for the Humanization of the Brazilian Unified Health Service, expressed in the Amplified and Shared Clinic $^{(9)}$, involves health education to achieve individual autonomy and freedom, in which scientific knowledge is not imposed vertically, but is made available to people clearly and in a way appropriate to their level of understanding, promoting conditions such that they may better deal with their condition.

Qualified listening, creating spaces for links and mutual confidence and making the practice of dialog and joint construction of knowledge possible, is part of a vision for health promotion based on the Amplified and Shared Clinic, in which individuality must be respected, people are once more placed as responsible for their lives, and the professional's technical knowledge alone is insufficient to promote the autonomy of the person with a stoma ${ }^{(6,9)}$.

The authors' practical experience with people with intestinal stoma has led them to question the care which has been given, as even after a relatively long period since the surgery, these people remain with doubts and are unaware of care steps which are important for keeping themselves healthy. The authors have questioned the changes which the policies promoting humanization have effectively promoted, and whether these policies meet the peculiarities of these people's different conditions. Due to these factors, the authors recommend the relevancy of carrying out an evaluative study of the care given to people with intestinal stoma permitting the recognition of the advances made - and of the remaining gaps.

The authors therefore undertook a study with the objective of investigating the care given in the health services to people with intestinal stoma from the perspective of the articulation of the actions proposed in the Amplified and Shared Clinic aiming at the promotion of the autonomy of people who received a stoma in a metropolitan region in the south of Brazil.

\section{Method}

This was a qualitative study undertaken in the perspective of the Amplified and Shared Clinic. The 
study's starting points were three public general hospitals - one federal and two state - in a metropolitan region of the south of Brazil, responsible for the highest number of intestinal stoma operations in the region. Subsequent to the identification of the people who had received stoma surgery in the hospitals, the other stages were carried out in the residences of the people with stomas. These institutions were defined as research locales because they allowed the recognition and identification of the people who underwent the surgery in this period, promoting the opportunity for first contact with the same and/or their family members.

Sampling was done in an intentional fashion, seeking to include all the people who had undergone the surgery in the period established for the first stage of data collection - that is, the period January - April 2011. The total number of operations for intestinal stoma in the period was 14. Two people did not enter as participants in the research due to living outside the region established; one person declined to participate in the research; and one person remained hospitalized for a long period due to complications referent to the cause of the stoma, which inviabilized his participation in the time of the data collection period.

In this way, the participants were 10 people who had undergone intestinal stoma, plus their family carers, resident in the metropolitan region, in these three hospitals.

The participants' identification occurred in the hospital institution through weekly visits to the institutions by the researcher, looking for those who had undergone this surgery. The first contact made with the participants took place in the hospital, in the post-operative period, when the research's purpose was explained and the subject invited to participate in the same.

Data collection was through two distinct interviews for each of the 10 participants, totalling 20 interviews. These interviews occurred in the residences of the people with stomas, after these had consented to the same and the interviews had been arranged by telephone.

The first interview happened approximately 30 days after discharge from hospital and was guided by a semi-structured script in two parts: the first containing socio-economic data, and the second, questioning the participants about the health care received in its different dimensions, based on the guideline of the Amplified and Shared Clinic. The second interview took place approximately 90 days after discharge, and aimed to investigate how the process of learning and adaptation on the part of the person with the new condition of a stoma occurred, following the approach of the Amplified and Shared Clinic. Following the participants' consent, with guidance about anonymity, the research's objectives, and signing of the Terms of Free and Informed Consent, all the interviews were recorded. All interviews were transcribed in full.

For data analysis, Trentini and Paim's(10) proposal was used. This has a process of analysis made up of four stages, termed: anxiety, where the information is grouped according to similarities, with the help of theoretical material for the organization of the data; synthesis, a process in which the subjective analysis of the information occurs, effecting the association and grouping of the previous codifications, constituting the categories; theorization, forming part of a process seeking the study's theoretical references and carrying out comparative analysis, discovering the values of the existing information and the study's conclusions; and the process of recontextualization, which refers to the socialization of the results and to the necessary observations.

The ethical precepts contained in Resolution $n^{\circ}$ $196 / 96$ CNS/MS ${ }^{(11)}$ were respected, along with its provisions which rule on regulatory Directives and Norms in Research Involving Human Beings. This study was approved by the Federal University of Santa Catarina's Research Ethics Committee in December 2010, under protocol number 1106/2010; by the Research Ethics Committee of Hospital Governador Celso Ramos, under number 0062/2010; and by the committee of the São José Regional Hospital, under number 72/2010.

To maintain the participants' confidentiality, they were identified by the letters PS1, PS2, PS3 and so on, in accordance with order of collection, with the letter $\mathrm{P}$ referring to Person, and the letter $\mathrm{S}$ to Stoma; their family carers who participated in the interviews were identified as CPS1; CPS2 and so on, with the letter C indicating Carer for person with stoma.

\section{Results and Discussions}

In this study, the authors identified a pattern among the people with stoma interviewed, related to the process of the development of their autonomy. To illustrate this, a figure was elaborated, showing the 90 days after surgery, relating data about what or who influenced the process of the construction of their autonomy.

As the process is visualized in Figure 1 , the results are described in four categories, which express 
the different stages identified in the study: The need to carry out care for the stoma; Health support and attention following discharge from hospital; The family carer's support in developing autonomy; Return to daily activities and social reinsertion.

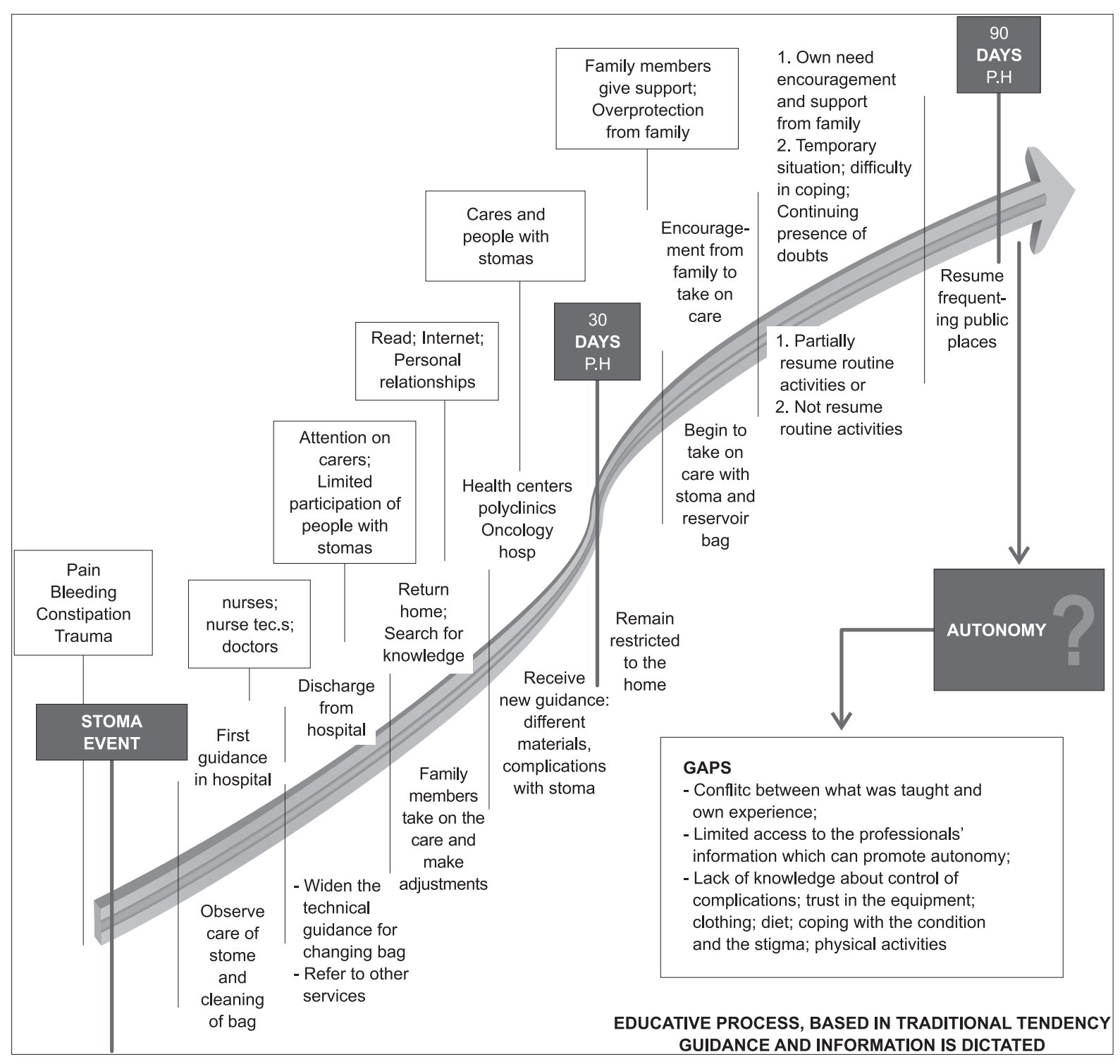

Figure 1 - Process of development of autonomy in people with intestinal stoma

\section{The need for carrying out care of the stoma}

The participants in the research received the first technical guidance related to specific care for their stomas from the health professionals in the hospital institutions. This information was given through demonstration by the health team, especially the nurses, on how to carry out cleaning and changing of the reservoir bag.

The guidance, at that time, was particularly directed at family members accompanying the patients, these being called to observe, and encouraged to undertake the care.
The initial demonstration of care of the stoma and the skin around the stoma, and the progressive training for self-care, form part of the educative strategies indicated, such that when the person with a stoma is discharged from hospital, they and/or a family member should be able to clean the stoma and the skin, and change and maintain the collection equipment ${ }^{(12-13)}$. Knowing how to undertake these specific care actions is a determining factor for the practice of self-care.

The association between self-care and the achievement of autonomy is inevitable, especially for people in this chronic condition who need to acquire 
specific skills in caring for the stoma and in the use of the collective equipment and the associated materials ${ }^{(5,7)}$.

Health care entails assistential care linked with educative practice. Providing guidance for self-care is the health professional's role, doing this gradually and carefully, offering technical information, integrating what is new with the person's previous knowledge, aiming for the promotion of autonomy. In this context, the aim of the practice of health education is the emancipation and liberty of the person, who, when sufficiently guided about their new condition, is able to take safe and informed decisions, exercising control over their own life and self-care, even taking into account the limitations imposed by the new condition(14-15).

Reflecting on the actions of the Amplified and Shared Clinic $^{(9)}$ and the influence which this has on health care given from this perspective, it was possible to note that the participants do not recognize the spaces for user embracement, listening and dialog, nor the openness of the health professionals to their needs. In spite of the guidance for technical care having been given, many doubts, going beyond the stoma itself, remained; and insecurity about living with this new condition was also present.

A nurse came, did it and showed my daughter how the cleaning was to be done. So she did it there close to my daughter and that's, that's how it works. From then on it's your responsibility. So it's something which leaves you scared right from the start. It's something new you don't know, you don't know the procedure. They showed it once, just once, and said to my daughter "from now on, that's how you have to do it, the responsibility is yours." (PS4)

When talking of listening spaces, the authors are referring to the willingness of the health professionals to pay attention to the person's speech, their gestures and their differences. Through this practice, the health professionals recognise the issues to be addressed, as the expressions of the persons attended direct the educative action for their anxieties and hopes. For this reason, the health professional needs to understand what fundamental individual point is to be worked on in the educative process and needs to use dialog to promote knowledge with a view to autonomy ${ }^{(16)}$.

The authors note that the technical viewpoint, still very present among these health professionals who attend people with stoma, needs to be widened, changing the "object" of work, seen as the patient, who is inert to the decisions - where the guidance is dictated - and, perceiving the person as a concrete singular subject, with ability to dialog and work in the perspective of the Shared Clinic.

\section{Support and health care after discharge from hospital}

The authors identified that as part of the guidance process, the people with stoma and their family members were informed during the period of inpatient treatment about the health services which they were to seek after returning home, and were referred to these with the necessary documentation.

Leaving hospital is a special moment, as on leaving this institution, the person no longer has access to the physical, material and professional resources which until then were available - and needs to face the home environment with the existing resources ${ }^{(12)}$.

To acquire his or her autonomy, the person needs to initiate daily and constant care of the equipment, which is no easy task, as it keeps the patient in direct contact with the surgical site, with their altered body image, with direct handling of their feces and the awareness of their limitations, arising from the stoma. The use of the equipment forces the person with a stoma to face the real change which has occurred with the surgery ${ }^{(17)}$.

The authors noted the health professionals' care in correctly referring the people to the health services indicated, in accordance with their needs, with the aim of promoting health care's support at the different levels of complexity. Through this referral, the people sought the services for their care in primary care or in centers of excellence. These places provided care, gave more extended guidance and had the equipment necessary for the care available, providing access to reservoir bags and to associated materials.

The guarantee of access to the specific equipment provided the people with security, as they knew that the bags and quality material were available for them to carry out the care, which positively influenced their personal autonomy.

Unfortunately, the authors noted that in primary care, offered by the capital's Health Centers, attendance was restricted to distribution of the equipment, without the health professionals giving any type of guidance or care specific to the stoma.

In order to care for the health of people with stomas the Health Centers have essential responsibilities and are fundamental parts of the healthcare network, with actions of guidance for self-care and the prevention of complications with the stoma being a duty of the health professionals in this area(18). These Health Centers are considered to be the institutions closest to these people's 
social reality and, due to this, are expected to have greater ease in creating links with the service users and in establishing interpersonal, social and environmental relationships, which may influence the achievement of autonomy.

The authors also noted in the research that the people received care which was limited to technical aspects of stoma care, as it did not include aspects related to alterations in diet, in the possibility of physical effort, as well as what to wear, returning to work, and social reinsertion.

The difficulty is that I haven't gone out yet. I have parties to go to, things like that, weddings, I always used to wear smart clothes to go out, and now I'm worried about how I'm going to get my pants on, you know, because I'm not fat, so I used to wear pants like this, nearly close to my navel, so now, how am I going to tuck my shirt into my pants? And what am I supposed to do with the bag? This is really worrying me. I used to like - I was always well-dressed, everybody used to comment, and now I don't know what I'm going to do. (PS10)

The need for health professionals who are prepared for attending these people is fundamental, as appropriate support in health care, linked with guidance, facilitates acceptance of the situation and these people's return to their activities with greater security. The guides developed by specialists in the area indicate the importance of addressing the issues, covering health education for a variety of aspects: physiological, nutritional, recreational and social, as well as those related to clothes, medications, body image, psychological support, personal relationships, sexuality, complications related to the surgery, and the resources available ${ }^{(12-13,19)}$.

However, the research ascertained that the viewpoint of the majority of health professionals remains centered on the technical aspects, this being a limiting factor in the development of personal autonomy. The guidance was dictated, often, without attention to individual needs and to their return to the home environment. There was not always commitment to the people's and family members' understanding of the guidance, which was given in an automatic way. For this reason, there was no development of these people's coautonomy in conjunction with the professionals, which as stated previously is an essential link.

It was identified that through the influence of the institution, the professionals and personal research, thirty days post-discharge the people with stoma and/or their family members know how to handle the equipment for stoma care and are familiar with the process of cleaning and adjusting the reservoir bag and how to use some of the associated materials, such as the activated charcoal filter and the hydrocolloid paste and powder for protecting the skin. The authors also noticed that the people make their first adaptations to the care, as they recognize specific individual conditions which render the basic technical guidance inadequate or non-ideal. These changes occur in situations such as, for example, whether or not to use the associated materials, the type of bag preferred, the appropriate diet, positioning for adjusting the bag and the need for help, among others.

Autonomy requires more than just the carryingout of care in conventional situations. The health professionals have an important role in preparing people with a stoma to face situations mindfully and to take decisions when necessary.

I can't manage to change it myself, because of the position, because I have to stay lying down, $[\ldots]$ and sitting up won't do, because when you apply the bag, you have to do it right, so that it doesn't pull at your skin and annoy you. So, what I mean to say is, there always has to be somebody else to do this. (PS7)

One can see from this account, common among participants in this research, that observation of the care carried out by the health professional in the hospital institution influenced how it was carried out in the home. These people were probably lying down in their hospital beds when the health professionals undertook their care of the stoma and the adjustment of the reservoir bag and - due to this - it was perceived that the adjustment of the bag always had to be done in that position. This situation reflects the lack of appropriate communication on the part of the team, with a view to the person's understanding, and to the practice of self-care, and, consequently, to the construction of autonomy.

The health services can work so as to attenuate the implications brought by the condition and by the loss of autonomy and self-control. For this, the health professionals need to be prepared to provide care with a view to maintaining or re-establishing personal identity to deal with the emotions and social stigmas ${ }^{(15)}$.

\section{Returning to daily activities and social reinsertion}

Concerning the return to daily activities, a division of people occurred: some initiated the process, gradually taking up their activities once more, while others preferred to remain restricted to their homes, dependent on family carers, waiting for the alreadyarranged surgical anastomosis.

What am I supposed to do? What am I going to do, with this 
thing here (points to stoma)? I can't work. You have to be whole to work in my profession. No, because I can't do anything. I hang around the house, as they say, doing my treatment, taking care of myself, but I can't do anything, not while I've got this here, I can't do anything. (PS1)

The difficulty in returning to social or work activities may occur because of the limits imposed by the surgery's physical changes, or because of the change in body image and self-esteem, as well as because of the fear of the social stigma related to the condition, which may also, sometimes, influence its acceptance(3-20).

One quantitative study sought to identify the return to social and work activities of people who had undergone this same surgical intervention. It was identified that the majority of people resume their activities, either totally or partially. Those who did not resume their activities attributed this difficulty to factors such as insecurity, physical problems, difficulty in cleaning the bag, shame, and others ${ }^{(21)}$, corroborating the factors found in the accounts of the participants in the present study.

Health professionals have an important role in addressing the alterations in body image and the representation of loss of sphincter control, so as to promote knowledge and personal self-esteem, demystifying the stigma created and positively influencing social reinsertion, and consequently producing a further advance for personal autonomy.

\section{Final considerations}

The information given by the health professionals to the people and their family members about specific technical care helped in developing the skills necessary to care for the stoma and handle the equipment. The family members left the hospital institution with a certain basic skill for carrying out this care. They gradually took on the responsibilities and began to undertake the selfcare with the stoma and the reservoir bag.

In spite of this essential skill, the authors note the lack of an amplified shared health care in which the health professionals value the person in his or her uniqueness and elaborate activities with a view to preparing for facing daily life, and the process of developing personal autonomy.

The Amplified and Shared Clinic is an important directive, proposing practical actions which can address issues like this, as the opportunities created by the proposed actions make it possible to recognize and understand the individual process, and thus to be able to work in line with emerging needs.

The health professional needs to get beyond the technical work and the verticalized attendance in favor of practice from the viewpoint of the Amplified and Shared Clinic, so as to practise dialog and to permit the creation of links and health education, factors which are fundamental to support the person with a stoma, to reflect on his or her decisions - and thus to develop a co-autonomy.

The authors noted that the people with stomas, in the 90 days post-discharge - despite this being a short period for adaptation - started to resume or develop their personal autonomy, some more than others, taking responsibility for self-care, gradually returning to their daily routine and taking responsibility for some personal decisions, although not to the full extent of their capability.

This study allowed the authors to understand which factors can influence people with stomas to develop or resume their autonomy, and how it is that the health professionals are fundamental to this process, working as educators, supporting the achievement, and encouraging the care and the return to activities.

\section{References}

1. Martins ML, Perugini VC, Silva RDM. Processo de viver com estomia: facilidades e limites. Rev Estima. 2006;4(1):15-20.

2. Salimena AMO, Valente WR, Melo MCSC, Paschoalin HC, Souza IEO. Compreendendo as vivências de mulheres ao enfrentar a condição de ter um estoma intestinal. Rev Estima. 2008;6(3):12-8.

3. Cascais AFM, Martini JG, Almeida PJS. O impacto da ostomia no processo de viver humano. Texto Contexto Enferm. 2007;16(1):163-7.

4. Monge RA, Avelar MCQ. A assistência de enfermagem aos pacientes com estomia intestinal: percepção dos enfermeiros. Online Braz J Nurs. [periódico na Internet]. 2009 [acesso 12 set 2011]; 8(1). Disponível em: http:// www.objnursing.uff.br/index.php/nursing/article/ view/j.1676-4285.2009.2208/468.

5. Campos GWS. Clínica e saúde coletiva compartilhadas: teoria Paidéia e reformulação ampliada do trabalho em saúde. In: Campos GWS, Minayo MCS, Akerman M, Drumond M Júnior, Carvalho YM. Tratado de Saúde Coletiva. São Paulo: Hucitec; Rio de Janeiro: Ed. Fiocruz; 2006. p. 41-80.

6. Onocko Campos RT, Campos GWS. Co-construção de autonomia: o sujeito em questão. In: Campos GWS, Minayo MCS, Akerman M, Drumond M Jr, Carvalho YM, organizadores. Tratado de Saúde Coletiva. São Paulo: 
Hucitec; Rio de Janeiro: Ed. Fiocruz; 2006. p. 669-88.

7. Oliveira DLLC. A enfermagem e suas apostas no autocuidado: investimentos emancipatórios ou práticas de sujeição? Rev Bras Enferm. jan-fev 2011;64(1):185-8.

8. Fleury-teixeira P, Vaz FAC, Campos FCC, Álvares J, Aguiar RAT, Oliveira VA. Autonomia como categoria central no conceito de promoção de saúde. Ciência Saúde Coletiva. 2000;3(2):2115-22.

9. Ministério da Saúde (BR). Secretaria de Atenção à Saúde. Política Nacional de Humanização da Atenção e Gestão do SUS. Clínica ampliada e compartilhada. Brasília: Ministério da Saúde; 2009. 64 p.

10. Trentini M, Paim L. Pesquisa convergente assitencial: um desenho que une o fazer e o pensar na prática assistencial em saúde-enfermagem. 2 ed. Florianópolis: Insular; 2004.

11. Conselho Nacional de Saúde (BR). Diretrizes e normas regulamentadoras de pesquisa envolvendo seres humanos [base de dados na Internet]. Brasília: Ministério da Saúde; 1996 [acesso 19 jun 2010]. Disponível em: http://portal.saude.gov.br/portal/ arquivos/pdf/sisnepabrasco.pdf.

12. Cesaretti IUR. Cuidando da pessoa com estoma no pós-operatório tardio. Rev Estima. 2008;6(1):27-32.

13. Wound Ostomy and Continence Nurses Society (WOCN). Management of the patience with a fecal ostomy: best practice guideline for clinicians. New Jersey: WOCN; 2010. 44 p.

14. Bellato R, Pereira WR, Maruyama SAT, Oliveira PC. A convergência cuidado-educação-politicidade: um desafio a ser enfrentado pelos profissionais na garantia aos direitos à saúde das pessoas portadoras de estomias. Texto Contexto Enferm. abr-jun 2006;15(2):334-42.

15. Entwistle VA, Carter SM, Cribb A, MCcaffery Kirsten. Supporting Patient Autonomy: The Importance of Clinician-patient Relationships. J Gen Intern Med. 2010;25(7):741-5.

16. Freire P. Pedagogia do Oprimido. Rio de Janeiro: Paz e Terra; 1987.

17. Silva A, Shimizu HE. O significado da mudança no modo de vida da pessoa com estomia intestinal definitiva. Rev. Latino-Am. Enfermagem. 2006 julago;14(4):483-90.

18. Ministério da Saúde (BR). Portaria no 400, de 16 de novembro de 2009 [base de dados na Internet]. Brasília: Ministério da Saúde; 2009 [acesso 9 maio 2010]. Disponível em: http://bvsms.saude.gov.br/bvs/ saudelegis/sas/2009/prt0400_16_11_2009.html.

19. Registered Nurses' Association of Ontario (RNAO). Ostomy Care and Management. Clinical Best Practice Guidelines. Toronto, Canadá: iaBPG; 2009.

20. Barnabe NC, Dell'acqua MCQ. Estratégias de enfrentamento (coping) de pessoas ostomizadas [periódico na Internet]. Rev. Latino-Am. Enfermagem. 2008 jul-ago [acesso 26 set 2011]; 16(4): [8p] Disponível em: http://www.scielo.br/pdf/rlae/v16n4/ pt_10.pdf.

21. Bechara RN, Bechara MS, Bechara CS, Queiroz HC, Oliveira RB, Mota RS, et al. Abordagem Multidisciplinar do Ostomizado. Rev Bras Coloproct. 2005;25(2):146-9. 